\title{
二维材料: 潜力无限的材料家族
}

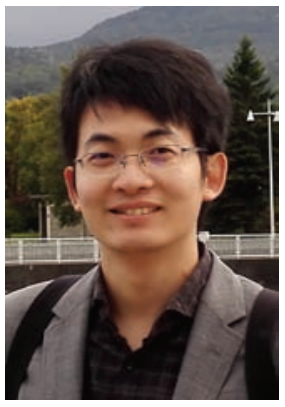

\section{付㣌}

武汉大学教授, 博士生导 师, 教育部青年长江学者, 国家自然科学基金委优秀 青年基金获得者。以电子 信息、能源领域应用为导 向, 着力研究石墨烯等二 维材料及其异质结的可控 生长、组装问题, 在 Nature Communication, Advanced Materials, Journal of the American Chemical Society 等国际一流刊物上发表论 文 100 余篇并被广泛引用, 申请发明专利 15 项。翻译 国内首部石墨烯学术专著 《石墨烯: 基础及新兴应 用》。
二维材料具有诸多令人瞩目的物理、化学性质, 使其成为目前国际材料科学 研究的前沿焦点. 自 2004 年被首次制得以来, 石墨烯在电学、光学、热学和力 学等方面均已展现出十分优异的性能. 由于石墨烯卓越的性能源于量子限域效 应, 研究者随即开始探索其他性能出众的新型二维原子晶体材料, 包括六方氮化 硼、过渡金属二硫族化合物、黑磷和过渡金属碳化物等。他们性质多样且互补, 涵盖了从导体、半导体、超导体到绝缘体各种类型. 从最初的输运性质, 到光电 器件和自旋电子器件, 再到后来的光/电催化剂、锂电池、太阳能电池、超级电 容器等, 二维材料已渗透入众多现有的研究领域甚至开拓出一些新兴领域, 有 望在下一代信息传输器件和能源存储器件领域得到广泛应用.

虽然二维材料的制备表征、性质探索和器件应用都已取得长足的发展，但与 实际应用和产业化需求还有相当远的距离, 如大面积均匀的二维材料及其特定 复合结构的可控制备、基于二维材料及异质结的新型低能耗高集成器件的结构 设计、新型大规模器件的构筑印刷技术等, 均有待进一步发展. 此外, 二维材料 家族中仍有不少备受期待的新材料尚未被制得, 部分二维材料的物理、化学性质 也有待揭示.

在竞争极为激烈的国际材料科学研究大环境下, 我国在二维纳米材料研究 领域取得了许多重要突破, 在新材料性质探索、材料可控制备与器件组装等方面 均取得了令人瞩目的成绩, 做出了许多开创性的工作. 为了集中展示我国学者 在本领域的研究成果, 激发社会各界对二维材料领域的兴趣, 推动同行们之间 的学术交流, 《科学通报》特此组织出版“二维材料与器件”专题. 该专题收入了 二维材料相关的研究进展和综述文章, 涵盖了石墨烯、六方氮化硼、过渡金属二 硫族化合物和黑磷等其他一些新型的二维材料, 以及二维材料的性质调控和异 质结构筑及应用等主要研究方向. “二维材料与器件( I )”侧重二维材料的制备, 主要涉及石墨烯、六方氮化硼等传统二维材料和黑磷、第四主族金属硫族化合 物、第五主族元素烯等新型二维材料, 同时包含异质结这类重要的二维材料的复 合结构, 从材料的可控制备、性质调控和器件应用三方面详细介绍了二维材料的 研究进展. “二维材料与器件 (II)”专题则侧重二维材料在器件和能源方面的应用, 主要涉及到二维材料在光电检测、锂离子电池、电解水、气体传感及逻辑集成 器件方面的应用. 希望通过该专题的出版, 让广大读者深入了解二维材料的研 究现状, 为我国的二维材料研究注入新的活力.

在此, 对参与本专题的所有作者、审稿人及编辑部工作人员的辛勤劳动表示 衰心的感谢!

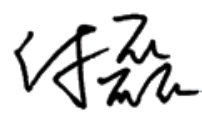

武汉大学化学与分子科学学院 